\title{
Can native plant species be preserved in an anthro- pogenic forest landscape dominated by aliens? A case study from Mediterranean Chile
}

\author{
S. Heinrichs, C. Stiehl, B. Müller-Using
}

Heinrichs S., Stiehl C., Müller-Using B., 2016. Can native plant species be preserved in an anthropogenic forest landscape dominated by aliens? A case study from Mediterranean Chile. Ann. For. Res. 59(1): 75-90.

Abstract. Plantations with fast growing exotic tree species can negatively affect native plant species diversity and promote the spread of alien species. Mediterranean Chile experienced major landscape changes with a vast expansion of industrial plantations of Pinus radiata in the past. However, with increasing knowledge of biodiversity effects on ecosystem services Chilean forest owners now aim to integrate the conservation of native biodiversity into forest management, but data on native species diversity and establishment within a plantation landscape is scarce. Here we investigated plant species diversity and composition in four forest management options applied within a landscape dominated by $P$. radiata plantations in comparison to an unmanaged reference: (i) a clear cut, (ii) a strip cut, (iii) a native canopy of Nothofagus glauca and (iv) a young $P$. radiata plantation. We wanted to assess if native plant species can be maintained either by natural regeneration or by planting of native tree species (Nothofagus glauca, $N$. obliqua, Quillaja saponaria) within this landscape.

Results show a high diversity of native and forest plant species within the different management options indicating a high potential for native biodiversity restoration within an anthropogenic landscape. In particular, herbaceous species can benefit from management. They are rare in unmanaged natural forests that are characterized by low light conditions and a thick litter layer. Management, however, also promoted a diversity of alien species. The rapid spread of alien grass species after management can deter an initial establishment of native tree species or the survival and growth after planting mainly under dry but less under sufficient moisture conditions. The most unsuccessful option for promoting native plant species was clear cutting in a dry area where alien grasses were abundant. For drought-tolerant tree species such as Quillaja saponaria, though, even a joint establishment with Pinus radiata seems possible.

Keywords Pinus radiata plantations, Nothofagus obliqua, Nothofagus glauca, Quillaja saponaria, invasive species 
Authors. Steffi Heinrichs (sheinri@gwdg.de), Carolin Stiehl - Department Silviculture and Forest Ecology of the Temperate Zones, Georg-August-University Göttingen, Büsgenweg 1, 37077 Göttingen - Germany; Burkhard Müller-Using - Facultad de Ciencias Forestales, Universidad de Concepción, Casilla 160-C, Concepción, Chile.

Manuscript received August 27, 2015; revised December 21, 2015; accepted January 4, 2016; online first January 28, 2016.

\section{Introduction}

Land use change and the introduction of alien species are the most important drivers of biodiversity loss in the Mediterranean (Sala et al. 2000). Here biodiversity hotspots usually coincide with areas of high population density and land use intensity (Myers 1990, Cincotta \& Engelman 2000). In particular, the expansion of tree plantations with fast growing exotic tree species can negatively affect native species diversity (Bremer \& Farley 2010), although some authors argue that plantations can as well support the regeneration of native understorey species (Lugo 1997, Carnus et al. 2006).

Mediterranean Chile, a biodiversity hotspot (Myers 1990, Myers et al. 2000), experienced major landscape changes in the past decades as exotic forest plantations expanded. At the same time natural ecosystems declined substantially and alien species invaded (Aguayo et al. 2009, Fuentes et al. 2013). The highly productive and diverse coastal ranges were particularly affected by deforestation as seen for the Coastal Maulino Forest dominated by the endemic and endangered tree species Nothofagus glauca at latitudes between $35^{\circ} 55^{\prime}$ and $36^{\circ} 20^{\prime}$ S (Litton \& Santelices 1996, Muñoz et al. 2013). Approximately $76 \%$ of the original area covered by this forest type has been replaced by Pinus radiata resulting in a highly anthropogenic landscape that contains only small isolated remnants of the natural forest (Echeverría et al. 2006).

Both plantations and natural forest fragments are largely affected by the invasion of alien species (Becerra \& Simonetti 2013), which can potentially decrease native species numbers and lead to local extinctions (Gaertner et al. 2009). Little is known about the diversity of native plant species and their successful regeneration in this anthropogenic landscape dominated by aliens. The restoration of natural forest communities and the conservation of native biodiversity is, however, becoming an increasingly relevant issue for some Chilean forest owners to obtain forest certification (Cubbage et al. 2010) or to promote ecosystem services (Lara et al. 2009). Furthermore, since 2008 forest owners can receive subsidies for a sustainable management of natural forests, whereas the conversion to plantations is forbidden (Müller-Using \& Bava 2010). Thus, knowledge on native species establishment is crucial.

By conducting vegetation surveys we investigated plant species diversity and composition of an intensively managed forest site in comparison to an unmanaged natural reference stand to evaluate the sites potential for native species establishment. The site represents four management options that may be used for the regeneration of native tree species in Mediterranean Chile: a clear cut, a strip cut, a native canopy of a small natural forest remnant and a young plantation of Pinus radiata. To assess the management options potential for native tree regeneration, three native tree species were planted within each option. These tree species were Nothofagus glauca, the dominant species of the Coastal Maulino forest, as well as Nothofagus obliqua and Quillaja saponaria colonizing more humid or dry sites of the Coastal Maulino Forest, respectively (San 
Martín \& Donoso 1995). Our questions were: (i) How much do native species diversity and composition in the managed site differ from an unmanaged reference stand?, and (ii) Can native tree species successfully regenerate in the different management options?

\section{Materials and methods}

\section{Study area}

The study was conducted in a private forest area situated between the localities Quirihue and Cobquecura within the Chilean coastal mountains at elevations between 370 and $550 \mathrm{~m}$ a.s.1. (36 $12^{\circ}-36^{\circ} 13^{\prime} \mathrm{S}$; $72^{\circ} 38^{\prime}$ $72^{\circ} 39^{\prime} \mathrm{W}$; see Supporting Information I). The study area is located in the north-western part of the Biobío-region according to the Chilean system of administrative regions. The climate can be classified as Mediterranean with an oceanic influence. The mean annual precipitation for the years 2010 to 2013 for the weather station Coronel del Maule (36 $\left.03^{\circ} \mathrm{S} ; 7^{\circ} 28^{\prime} \mathrm{W}\right)$, ca. $23 \mathrm{~km}$ north of the study site at an altitude of $165 \mathrm{~m}$ a.s.1, is $623 \mathrm{~mm}$, the mean annual temperature is $13.3{ }^{\circ} \mathrm{C}$. The precipitation is seasonal and concentrated during the winter season (Agromet 2015). Due to proximity to the ocean air humidity is high (Litton \& Santelices 1996). The predominant soil type is a fertile, well drained alfisol on igneous granite rock with a medium to fine texture and a high base saturation allowing a deep root development. The topography is hilly with slopes up to $>50 \%$ that are susceptible to erosion (Casanova et al. 2013).

The landscape is dominated by Pinus radiata plantations that comprise ca. 1.5 Million ha in Chile (2009). $44 \%$ are located in the Biobío-region (Mead 2013). The potential natural vegetation of the study area is a deciduous forest of Nothofagus glauca (deciduous Maulino Forest) with a scarce presence of $N$. obliqua accompanied by evergreen tree species (e.g.
Aextoxicon punctatum, Gevuina avellana) and epiphytes (e.g. Lapageria rosea Lardizabala biternata) corresponding to temperate rainforest communities and by elements of more northern sclerophyllous forest communities (e.g. Cryptocarya alba, Peumus boldus, Quillja saponaria).

\section{Management options and native tree species establishment}

In 2009 the forest company MASISA provided a forest site of ca. 2 ha in total for investigating native tree species establishment within the study area. The site was managed in the same year in four different ways (management options): (i) a 70 by $70 \mathrm{~m}$ Pinus radiata clear cut (CC); (ii) a 25 by $200 \mathrm{~m}$ strip cut (SC) of Pinus radiata and Eucalyptus spec. receiving lateral shade from adjacent Pinus radiata plantations; (iii) a ca. 25 year-old 70 by $70 \mathrm{~m}$ Nothofagus glauca remnant thinned by reducing stems per ha from 2250 to 553 (Native canopy option = NC); and (iv) a young Pinus radiata plantation established with one year old seedlings (670 seedlings/ha) on a ca. 40 by $135 \mathrm{~m}$ plot (Pine canopy option $=$ PC, see Table 1; Supporting Information I).

Pinus radiata plantations in central Chile are intensively managed in short rotation periods of 18 to 28 years (Mead 2013) with clear cuts followed by fertilizer and herbicide application and a subsequent re-planting with Pinus radiata. The management options CC and SC represent such a total canopy removal on a small scale with lateral shade being provided by adjacent plantations for the SC option. A buffer of one tree length to adjacent plantations was established for the CC option. Furthermore, no fertilizers or herbicides were applied after cutting operations, but understorey vegetation was removed mechanically. For these options a subsequent re-planting with the three native tree species Nothofagus obliqua, N. glauca and Quillaja saponaria occurred. A subsequent re-planting both with Pinus radiata and the 
Table 1 List of the four management options and their main characteristics

\begin{tabular}{|c|c|c|c|}
\hline $\begin{array}{l}\text { Managmement } \\
\text { option }\end{array}$ & $\begin{array}{l}\text { Abbrevation } \\
\text { used }\end{array}$ & Size $[\mathrm{m}]$ & Description \\
\hline Clear cut & $\mathrm{CC}$ & $70 \times 70$ & Clear cut of Pinus radiata \\
\hline Strip cut & $\mathrm{SC}$ & $25 \times 200$ & $\begin{array}{l}\text { Clear cut of } P \text {. radiata and Eucalyptus spec. with shade from adjacent } \\
\text { plantations }\end{array}$ \\
\hline Native canopy & $\mathrm{NC}$ & $70 \times 70$ & $\begin{array}{l}\text { Thinned } 25 \text { year old Nothofagus glauca stand (from } 2250 \text { to } 553 \\
\text { stems/ha) }\end{array}$ \\
\hline Pine canopy & $\mathrm{PC}$ & $40 \times 135$ & $\begin{array}{l}\text { Young plantation of } P \text {. radiata ( } 670 \text { seedlings/ha) after clear cut; } P \text {. } \\
\text { radiata forms the subsequent canopy }\end{array}$ \\
\hline
\end{tabular}

three native tree species was conducted for the PC option. Due to the much faster growth rate of Pinus radiata compared to the native trees a pine canopy developed that was assumed to provide shade for the native tree species. Since 2012 the pine trees were pruned.

The NC option represents a possible sustainable management option for regenerating the scattered natural forest remnants present in the anthropogenic landscape. Forest owners might get governmental subsidies for such a management option. The here considered forest remnant is a young secondary forest that developed from natural regeneration with stems in high density and small diameter. By thinning and subsequent planting of native tree species a diverse multi-layered natural forest may be achieved resulting in high native plant species diversity and economical valuable timber. In addition, the native forest remnant functions along with scattered groups of native trees as seed source for the study area.

In each of the four management options 300 one year old tree seedlings per native tree species were planted in September 2009. The trees were obtained from regional tree nurseries where they were grown in $130 \mathrm{~cm}^{3}$ pots. For each species 12 subplots with 25 seedlings were established per management option.

The 25 seedlings per subplot were planted in a distance of 2 by $2 \mathrm{~m}$ from each other. The subplots were separated by a $3 \mathrm{~m}$ distance from each other. The subplots containing the different tree species were arranged rotationally with two subplots of the same species being always adjacent to each other (see Supporting
Information II). To allow an initial establishment of the seedlings an early competition was prevented by mechanically removing the surrounding understorey vegetation above the ground once a year (March 2012 for the last time); root competition remained.

Survival of all seedlings was recorded at the end of each vegetation period in May until 2013 (in total after four vegetation periods).

Seedling height at time of planting was comparable between management options and species with a minimum of $15.4 \pm 0.4 \mathrm{~cm}$ for $N$. glauca in the CC option and a maximum of $19.3 \pm 2.1 \mathrm{~cm}$ for $N$. obliqua in the SC option and $19.3 \pm 0.4 \mathrm{~cm}$ for $N$. glauca in the PC option.

\section{Vegetation data sampling}

Vegetation data were sampled on 2 by $50 \mathrm{~m}$ transects divided into five 2 by $10 \mathrm{~m}$ subplots. In each management option five transects were sampled. On each subplot the presence and cover of all vascular plants $<5 \mathrm{~m}$ in height were recorded in November 2012. We checked for new species in each transect in February 2013. Species cover was estimated using the methodology of Braun-Blanquet (1964).

Vegetation data were contrasted to eight vegetation surveys conducted in an unmanaged reference on the same transect size ( 2 by $50 \mathrm{~m}$ divided into 2 by $10 \mathrm{~m}$ subplots). The unmanaged reference is a large-scale continuous forest dominated by Nothofagus glauca in a $3 \mathrm{~km}$ distance from the managed site (see Supporting Information I). With ca. 200 ha this 
forest represents the largest continuous natural forest within the whole study area. All species detected were classified as alien or native according to Zuloaga et al. (2008).

Furthermore, species typical for natural forest communities (in the following referred to as forest species) of the study area were distinguished from the literature (see Supporting Information III). Species were further grouped based on their growth form differentiating between trees, shrubs, vines, lianas, herbs, ferns and graminoids (Zuloaga et al. 2008).

\section{Environmental variables}

In each management option and in the unmanaged reference several environmental variables were assessed within the vegetation transects.

The light intensity is expressed by the indirect site factor obtained from a hemispheric photograph taken in the center of each subplot (i.e. five photographs per transect) at $2 \mathrm{~m}$ height in February when trees were fully foliated (Pryor 2010). We took soil samples from the upper $5 \mathrm{~cm}$ of the mineral soil in each subplot and pooled the samples per transect. The pooled samples were analyzed for $\mathrm{pH}$, total carbon and nitrogen pools and the carbon to nitrogen ratio. Litter layer thickness was measured in the center of each subplot resulting in five measurements per transect. We characterized the abundance of the shrub layer considering all woody species $<5 \mathrm{~m}$ and $>0.5 \mathrm{~m}$ in height and the abundance of the herb layer considering all woody species $<0.5 \mathrm{~m}$ and all herbaceous species by estimating percentage coverage per 2 by $10 \mathrm{~m}$ subplot for each transect.

The potential plant available water capacity (AWC) was quantified for the four management options in 2011. The AWC was quantified as the difference between water content at field capacity and water content at wilting point at $0-20 \mathrm{~cm}$ and $20-40 \mathrm{~cm}$ depth of the mineral soil. For this analysis soil samples were taken at three spots across each management option and separated by soil depth. In the laboratory water content of each sample was determined at 0.3 and 15 bar. These analyses were conducted using disturbed samples and can therefore only be used as a rough estimate for plant available water capacity (Bell and van Keulen 1996). The management options are comparable in terms of soil texture (sandy loam) and bulk density (1.25 to $\left.1.36 \mathrm{~g} / \mathrm{cm}^{3}\right)$. No estimation for available water content was conducted in the unmanaged reference.

\section{Data assessment}

For assessment of the vegetation data we contrasted (i) each management option with $n=5$ transects to the unmanaged reference with $\mathrm{n}=$ 8 transects and (ii) the managed forest site with $\mathrm{n}=4$ management options to the unmanaged reference.

Differences regarding environmental variables and species diversity sampled on the transect level were tested with t-tests when data was normally distributed or Mann-WhitneyU-Test when normality was lacking.

Species diversity was further compared between the managed site and the unmanaged reference by considering all available transects using rarefaction and extrapolation techniques proposed by Chao et al. (2014). 20 transects were regarded as the base sample size for contrasting the managed site with the unmanaged reference. As 20 transects were available for the managed site sampled in the four management options species diversity estimation is based on rarefaction here. Extrapolation was used for the unmanaged site with $\mathrm{n}=8$ transects. We regarded the first three Hill numbers with $\mathrm{q}=0$ representing species richness, $\mathrm{q}=1$ the exponential Shannon's entropy and $q=2$ the inverse of Simpson's concentration index. Analyses were performed for the entire data set, native species only and forest species only.

We further conducted non-metric multidimensional scaling (NMDS, metaMDS func- 
tion with Bray-Curtis-Distance within the vegan package; Oksanen et al. 2013) to investigate compositional differences in the understorey vegetation between the managed site with the four management options and the unmanaged reference. Analyses were performed on the entire data set, with native species only and with forest species only. We calculated the standard deviational ellipses (95\% confidence interval) for each management option using the ordiellipse function. We tested for significance of compositional differences between the managed site and the unmanaged reference for each species group using a non-parametric multivariate analysis of variance (PERMANOVA (PMAV), function adonis, 999 permutations, Bray-Curtis dissimilarity). This analysis performs permutational tests using distance matrices of the species composition of plots to find significant differences between the different treatments investigated.

If not stated otherwise results were considered to be significant with $\mathrm{p}<0.05$. Nomenclature of species follows Zuloaga et al. (2008).

\section{Results}

\section{Environmental variables}

Light availability, $\mathrm{pH}$, litter layer thickness and the shrub and herb layer cover significantly differed between the managed site and the unmanaged reference (Table 2). Each management option had a significantly higher light availability and lower litter thickness compared to the unmanaged forest. The shrub layer was more abundant in the unmanaged forest, whereas the herb layer had a greater cover in all management options. The $\mathrm{pH}$ value was always higher in the managed site. The CC option did not differ significantly from the unmanaged reference. The CC option had a significantly lower carbon and nitrogen content and a higher $\mathrm{C}$ to $\mathrm{N}$ ratio than the reference site. Contrarily, the NC option showed higher carbon and nitrogen contents but no difference in $\mathrm{C}$ to $\mathrm{N}$ ratio from the reference.

The four management options showed pronounced differences in AWC with highest values in the NC option followed by the SC and $\mathrm{CC}$ option and lowest values in the PC option indicating a high heterogeneity in water availability within the managed site (Table 2).

\section{Species diversity}

Across all sampled transects 151 species were recorded. 43 species were aliens, 39 species were classified as forest species. 40 species occurred both in the managed site and in the unmanaged reference, 28 species were only detected in the unmanaged stand and 83 species only in the managed site (see Supporting Information III).

Transect based species diversity was higher in the managed site compared to the unmanaged forest with all management options showing higher species numbers but with no significance for the CC option (Table 3). Most pronounced is the difference in the number of alien species being significantly higher in all management options compared to the unmanaged forest. The number of native and forest species sampled in transects of the managed site were not significantly different from the unmanaged reference, although the $\mathrm{CC}$ option (native species and forest species) and the PC option (forest species) had significantly lower species numbers.

In the unmanaged reference tree and shrub species were the most species rich growth group per transect but showed no significant difference to the managed site. In the managed site herbs had the highest diversity with higher numbers in all four management options compared to the unmanaged stand. Graminoids showed a similar pattern but with no significance for the NC option (Table 3).

The managed site also had a greater total plant species richness compared to the unmanaged reference (Fig. 1) for all investigat- 
Table 2 Environmental characteristics (mean \pm standard error) of each management option, the managed site as a whole and the unmanaged reference. Plant available water capacity was assessed for the management options only in 2011. All other variables were sampled in February 2013.

\begin{tabular}{|c|c|c|c|c|c|c|}
\hline & \multicolumn{4}{|c|}{ Management options } & \multirow[t]{2}{*}{ Managed } & \multirow[t]{2}{*}{ Unmanaged } \\
\hline & $\mathrm{CC}$ & $\mathrm{SC}$ & $\mathrm{PC}$ & $\mathrm{NC}$ & & \\
\hline $\mathrm{N}$ & 5 & 5 & 5 & 5 & 4 & 8 \\
\hline Light availability [\%] & $88.76 \pm 1.72 *$ & $79.08 \pm 2.51 *$ & $39.40 \pm 2.65^{*}$ & $44.68 \pm 2.38^{*}$ & $62.98 \pm 12.30$ & $8.28 \pm 1.38$ \\
\hline $\mathrm{pH}$ & $5.19 \pm 0.07$ & $5.72 \pm 0.14^{*}$ & $5.46 \pm 0.06^{*}$ & $5.95 \pm 0.04^{*}$ & $5.58 \pm 0.17$ & $5.10 \pm 0.12$ \\
\hline Carbon $[\%]$ & $6.89 \pm 0.45^{*}$ & $13.43 \pm 1.21$ & $9.05 \pm 0.92$ & $16.31 \pm 0.99^{*}$ & $11.42 \pm 2.12$ & $10.40 \pm 0.83$ \\
\hline Nitrogen [\%] & $0.23 \pm 0.01 *$ & $0.50 \pm 0.05$ & $0.36 \pm 0.04$ & $0.69 \pm 0.03^{*}$ & $0.45 \pm 0.10$ & $0.42 \pm 0.02$ \\
\hline $\mathrm{C} / \mathrm{N}$ ratio & $29.82 \pm 1.96^{*}$ & $26.80 \pm 0.84$ & $25.30 \pm 0.90$ & $23.73 \pm 0.69$ & $26.41 \pm 1.30$ & $24.81 \pm 0.84$ \\
\hline Litter layer thickness $[\mathrm{cm}]$ & $0^{*}$ & $2.00 \pm 0.45^{*}$ & $0.84 \pm 0.14^{*}$ & $2.16 \pm 0.22 *$ & $1.25 \pm 0.51$ & $7.08 \pm 0.91$ \\
\hline Shrub layer cover $[\%]$ & $7.44 \pm 3.83^{*}$ & $16.88 \pm 2.85^{*}$ & $8.12 \pm 3.88^{*}$ & $10.28 \pm 2.12^{*}$ & $10.68 \pm 2.15$ & $53.68 \pm 6.00$ \\
\hline Herb layer cover $[\%]$ & $85.32 \pm 2.58^{*}$ & $61.80 \pm 5.29^{*}$ & $34.60 \pm 3.36^{*}$ & $46.60 \pm 4.02 *$ & $57.08 \pm 10.94$ & $21.90 \pm 3.51$ \\
\hline \multicolumn{7}{|l|}{$\begin{array}{l}\text { Plant available water capacity } \\
{[\%]}\end{array}$} \\
\hline $\mathrm{N}$ & 3 & 3 & 3 & 3 & & \\
\hline $0-20 \mathrm{~cm}$ & $10.53 \pm 0.45$ & $17.77 \pm 3.34$ & $9.42 \pm 0.42$ & $21.01 \pm 3.39$ & & \\
\hline $20-40 \mathrm{~cm}$ & $9.01 \pm 0.23$ & $14.65 \pm 0.67$ & $7.70 \pm 0.58$ & $18.96 \pm 3.43$ & & \\
\hline
\end{tabular}

Note. Significant higher values comparing the managed site and the unmanaged reference are written in bold ${ }^{*}$ marks significant differences between each management option and the unmanaged reference. Abbreviations of the management option: CC - clear cut, SC - strip cut, PC - pine canopy, NC - native canopy.

Table 3 Species numbers per transect (mean \pm SE). Species were grouped according to origin and growth form for the four management options, the managed site as a whole and the unmanaged reference.

\begin{tabular}{|c|c|c|c|c|c|c|}
\hline & \multicolumn{4}{|c|}{ Management options } & \multirow[t]{2}{*}{ Managed } & \multirow[t]{2}{*}{ Unmanaged } \\
\hline & $\mathrm{CC}$ & $\mathrm{SC}$ & $\mathrm{PC}$ & $\mathrm{NC}$ & & \\
\hline $\mathrm{N}$ & 5 & 5 & 5 & 5 & 4 & 8 \\
\hline \multicolumn{7}{|c|}{ Species number/transect } \\
\hline All species & $31.80 \pm 2.31$ & $48.40 \pm 1.44^{*}$ & $39.40 \pm 1.75^{*}$ & $44.40 \pm 5.90 *$ & $41.00 \pm 3.58$ & $26.62 \pm 2.45$ \\
\hline \multicolumn{7}{|l|}{ Origin } \\
\hline Alien species & $14.20 \pm 0.49^{*}$ & $19.40 \pm 1.08^{*}$ & $14.60 \pm 0.87^{*}$ & $8.80 \pm 1.59 *$ & $14.25 \pm 2.17$ & $0.25 \pm 0.16$ \\
\hline Native species & $17.60 \pm 1.99 *$ & $29.00 \pm 1.76$ & $24.80 \pm 1.53$ & $35.60 \pm 4.49$ & $26.75 \pm 3.77$ & $26.38 \pm 2.43$ \\
\hline Forest species & $5.80 \pm 1.07 *$ & $11.80 \pm 1.20$ & $10.20 \pm 1.02 *$ & $18.08 \pm 1.41$ & $11.47 \pm 2.54$ & $15.75 \pm 1.67$ \\
\hline \multicolumn{7}{|l|}{ Growth form } \\
\hline Trees & $2.60 \pm 0.93 *$ & $7.80 \pm 0.86$ & $5.40 \pm 0.68^{*}$ & $11.80 \pm 0.66$ & $6.90 \pm 1.95$ & $9.00 \pm 1.09$ \\
\hline Shrubs & $4.60 \pm 0.25^{*}$ & $7.80 \pm 0.58$ & $5.40 \pm 0.98$ & $8.80 \pm 1.02$ & $6.65 \pm 0.99$ & $6.88 \pm 0.61$ \\
\hline Lianas & & $0.40 \pm 0.25$ & $0.80 \pm 3.70$ & $0.20 \pm 0.20$ & $0.35 \pm 0.17$ & $0.25 \pm 1.60$ \\
\hline Vines & $0.60 \pm 0.24 *$ & $1.20 \pm 4.90^{*}$ & $1.00 \pm 0.00 *$ & $1.80 \pm 0.37$ & $1.15 \pm 0.25$ & $2.87 \pm 0.40$ \\
\hline Ferns & & $0.20 \pm 0.20$ & & $0.20 \pm 0.20$ & $0.10 \pm 0.06$ & $0.62 \pm 0.18$ \\
\hline Graminoids & $7.40 \pm 0.51^{*}$ & $8.20 \pm 1.46^{*}$ & $9.80 \pm 0.37 *$ & $5.40 \pm 1.21$ & $7.70 \pm 0.91$ & $2.63 \pm 0.42$ \\
\hline Herbs & $16.60 \pm 1.12 *$ & $22.80 \pm 1.62 *$ & $17.00 \pm 1.79 *$ & $16.20 \pm 3.22 *$ & $18.15 \pm 1.56$ & $4.38 \pm 0.73$ \\
\hline
\end{tabular}

Note. Signs of significance and abbreviations are similar to table 2 . 

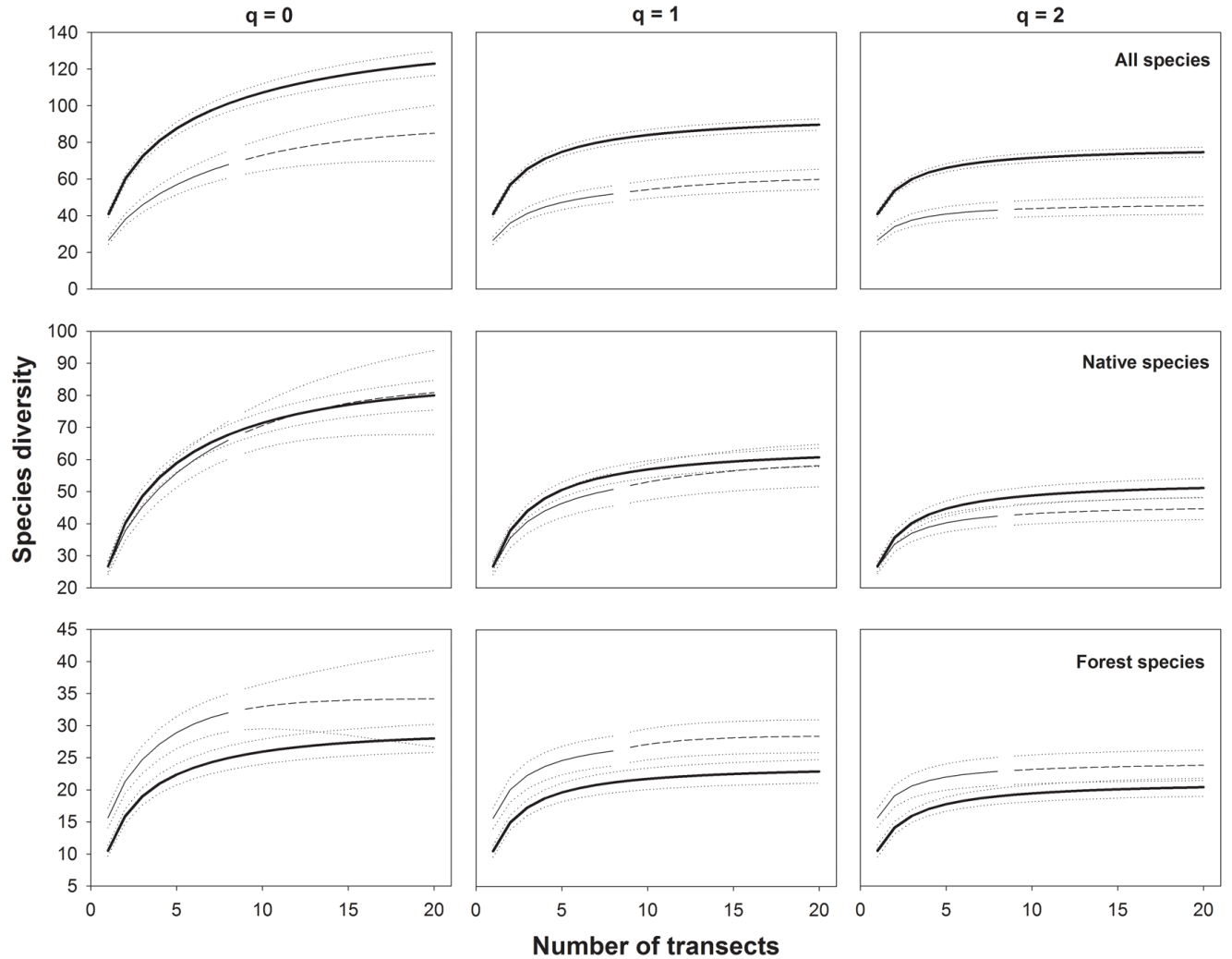

Figure 1 Sample-size based rarefaction (solid lines) and extrapolation (dashed line) of plant species diversity (distinguishing between all species, native species, forest species) for Hill numbers $q=$ $0,1,2$ for the managed site (bold line) and the unmanaged reference (thin line). The upper and lower $95 \%$-confidence intervals (dotted lines) were obtained by a bootstrap method based on 50 replications.

ed Hill numbers. Thus, the managed site contained more rare species as well as common species that are evenly distributed. There is no significant difference between the managed and unmanaged variant for native species as confidence intervals overlap for all Hill numbers. The higher diversity of the managed site is therefore a result of the high number of alien species occurring there. There is no native species diversity reduction compared to the unmanaged forest. Forest species were generally more diverse in the unmanaged forest. A significant difference with no overlap of confidence intervals could be detected for $\mathrm{q}=1$ at the base sample size of 20 . Thus, forest species show a higher evenness in the unmanaged forest.

When considering the four management options separately overall species diversity is higher for the PC option, the NC option and the SC option for $\mathrm{q}=0,1,2$ compared to the unmanaged reference (see Supporting Information IV). The CC option is not different from the unmanaged stand. Native species diversity was not different from the unmanaged reference except for the PC option at $\mathrm{q}$ $=0$ with lower species diversity here and for the CC option with lower species diversity at all Hill numbers. Forest species diversity was mostly higher in the unmanaged stand with an 

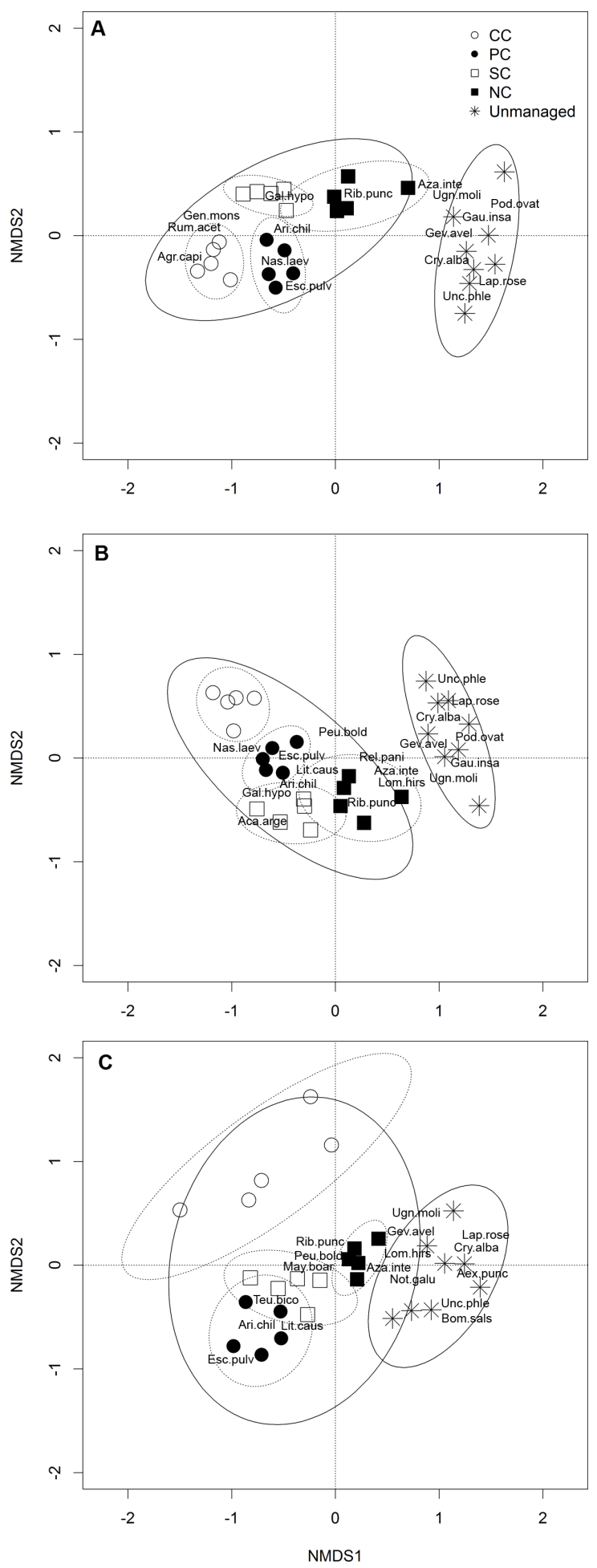

\section{Figure 2}

NMDS ordination of floristic composition data for the first two axes based on transects from the managed site and the unmanaged reference for A) all species, B) native species and C) forest species. The managed site is separated into the four management options (CC - Clear cut, PC - Pine canopy, SC - Strip cut, NC - Native canopy). The ellipses indicate the $95 \%$ standard deviational confidence interval around the centroids of the managed site and the unmanaged reference (solid lines) as well as the management options (dotted lines). Shown are the ten most abundant species for each research site: Aca. arge - Acaena argenter, Aex.punc - Aextoxicon punctatum, Agr.capi - Agrostis capillaris, Ari.chil - Aristotelia chilensis, Aza.inte - Azara integrifolia, Bom.sals - Bomarea salsilla, Cry.alba - Cryptocarya alba, Esc.pulv - Escallonia pulverulenta, Gal.hypo - Galium hypocarpium, Gau.insa - Gaultheria insana, Gen.mons - Genista monspessulana, Gev. avel - Gevuina avellana, Lap.rose - Lapageria rosea, Lit.caus - Lithrea caustica, Lom. hirs - Lomatia hirsuta, May.boar - Maytenus boaria, Nas.laev - Nassella laevissima, Not. glau - Nothofagus glauca, Peu.bold - Peumus boldus, Pod.ovat - Podanthus ovatifolia, Rel. pani - Relchela panicoides, Rib.punc - Ribes punctatum, Rum.acet - Rumex acetosella, Teu.bico - Teucrium bicolor, Ugn.moli Ugni molinae, Unc.phle - Uncinia phleoides. 
exception for the SC option at $\mathrm{q}=0$ indicating no difference in the occurrence of rare forest species and for the NC option for all Hill numbers. Thus, $\mathrm{NC}$ and the unmanaged forest do not differ neither in the number of rare nor equally distributed forest species.

\section{Species composition}

Considering all species and their cover values NMDS ordination shows a distinct difference in species composition between the managed site and the unmanaged reference (Fig. 1A, PMAV, $\left.\mathrm{R}^{2}=0.27, \mathrm{~F}=9.58, \mathrm{p}<0.001\right)$. The four management options are clearly separated from each other as well. The differences in species composition remain when only native species are regarded (Fig. 1B; PMAV, $\mathrm{R}^{2}=$ $0.27, \mathrm{~F}=9.83, \mathrm{p}<0.001)$. The ordination of forest species shows an overlap of the SD-ellipses of the managed site and the unmanaged reference. The difference in species composition is, however, still significant but with a reduction in $\mathrm{R}^{2}$ (Fig. 1C; PMAV, $\mathrm{R}^{2}=0.18, \mathrm{~F}$ $=5.63, \mathrm{p}<0.001)$. Bray-Curtis dissimilarities reveal a persistent difference in community composition between the managed site and the unmanaged reference independent of the considered species group (managed vs. unmanaged: all species $=0.907$; native species $=$
0.901; forest species $=0.906$ ).

While some species characterize both research sites (e.g. Azara integrifolia, Lomatia hirsuta, Relchela panicoides), some species are more abundant at the managed site (e.g. Aristotelia chilensis, Nassella laevissima, Maytenus boaria) or the unmanaged reference (e.g. Aextoxicon punctatum, Cryptocarya alba, Lapageria rosea) across all considered species groups. The alien species Agrostis capillaris, Genista monspessulana and Rumex acetosella were particularly abundant at the managed site (Fig. 2A). For each species group the CC option has the largest distance to the unmanaged reference. The NC option is closest.

\section{Planted tree species survival}

For the whole managed site with the management options as replicates $N$. obliqua showed a survival of $50.00 \pm 18.70 \%$, N. glauca of $49.50 \pm 14.64 \%$ and $Q$. saponaria of $66.08 \pm$ $13.43 \%$ after four vegetation periods.

Survival differed largely between the four management options with the two treatments with the highest light availability (SC and $\mathrm{CC}$ ) showing the largest differences for the two Nothofagus species after four vegetation periods (Fig. 3). Only $14 \%$ of both species survived on the CC compared to 93 ( $N$. obliqua)
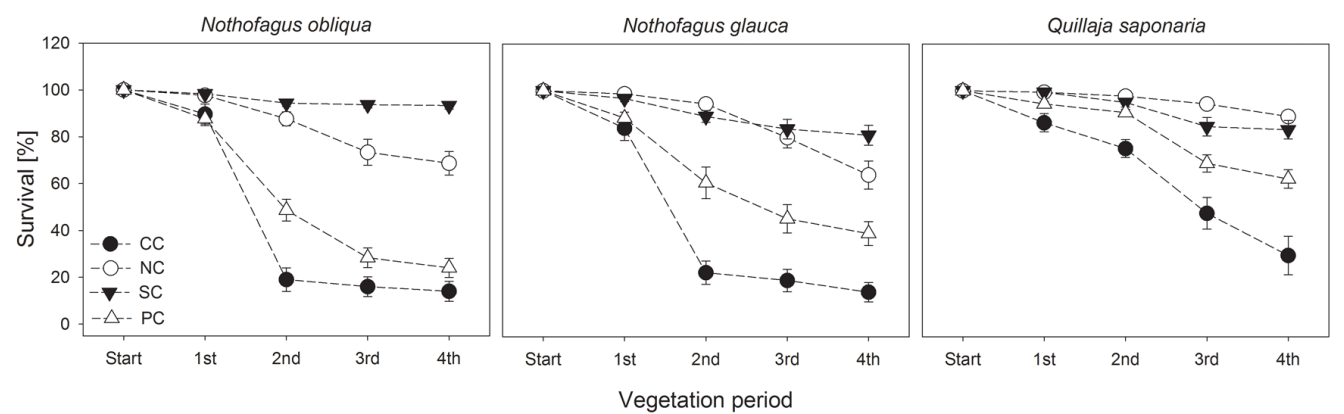

Figure 3 Percentage survival of planted Nothofagus obliqua, N. glauca and Quillaja saponaria seedlings on the four different management options (CC - clear cut, NC - native canopy, SC - strip cut, PC - Pine canopy) at the end of the first, second, third and fourth vegetation period based on 12 subplots per species and management option. One-year-old seedlings were planted in September 2009. Each vegetation period ended in May. 
and $81 \%$ (N. glauca) on the SC (Fig. 3). $N$. obliqua also barely survived under the PC (24 $\%$ ), whereas the percentage for $N$. glauca was slightly higher (39\%). Under the native canopy survival was comparable for both Nothofagus species (64\% N. glauca, $69 \%$ N. obliqua; Fig. 3).

The evergreen $Q$. saponaria had generally higher survival rates compared to both Nothofagus species. The CC was the most unsuccessful option for this species as well followed by the PC option. There was a small difference in survival of $Q$. saponaria between the SC (83\%) and the NC option (89\%) after four vegetation periods (Fig. 3).

\section{Discussion}

\section{Understorey diversity and composition}

Our results demonstrate that native and forest species diversity and evenness are not significantly reduced in a managed forest site compared to an unmanaged natural forest in Mediterranean Chile. Species composition, though, differs distinctively. In particular, herbs and graminoids were more diverse in the managed site. Although these species groups have the greatest richness in alien species, some native and even typical forest herbs and graminoids appeared exclusively in the managed site (e.g. Conanthera bifolia, Alstroemeria revoluta, Nassella chilensis, Chascolytrum subaristatum; see Supporting Information III).

As already described by Oberdorfer (1960) the central Chilean sclerophyllous forest is dominated by phanerophytes and characterized by a sparseness of the herb layer. The two environmental variables with the greatest difference between the managed site and the unmanaged reference were the light availability and the litter layer thickness, both explaining the differences in species composition. The low light availability in the unmanaged forest promotes very shade-tolerant tree species such as Aextoxicon punctatum or Cryptocarya alba (Hoffmann 2005, Figueroa \& Lusk 2001), which do not appear in the managed site or only in lower abundances. The thick litter layer further prevents an establishment of species within the natural forest. Studies of litter decomposition show lowest decomposition rates for $N$. glauca and C. alba, the dominant tree species within the investigated unmanaged forest, compared to other Nothofagus species and compared to Pinus radiata (Lusk et al. 2001, Palacios-Bianchi 2002). Thus, few open patches for colonization are available in the natural forest. The investigated unmanaged forest therefore represents a succession climax with a very stable understorey species composition dominated by phanerophytes, many of them being endemic (Armesto et al. 1995).

In contrast, herbaceous species and several tree and shrub species that are characteristic for open forest communities (Lomatia hirsuta, Aristotelia chilensis, Escallonia pulverulenta, Maytenus boaria, Teucrium bicolor) benefitted from open conditions after management and could successfully regenerate (Litton \& Santelices 1996, Luebert \& Pliscoff 2006, Guerrero \& Bustamante 2009). Eminent is the high native species diversity per transect in the thinned natural forest remnant compared to the unmanaged stand, though differences were not significant. Thus, sustainable small scale management operations can be beneficial for native species in such forest remnants that are known to be keystone for native species conservation in a landscape dominated by exotic plantations (Guerrero \& Bustamante 2009).

Despite these positive effects, management operations largely promoted alien species diversity even under a native canopy. With a total number of 43 alien species we recorded much more species across our relatively small managed site than found by other authors in Pinus radiata plantations in south-central Chile (Ramírez et al. 1984, Gómez et al. 2009, Becerra \& Simonetti 2013). Alien species are often light-demanding, short-lived and charac- 
terized by a high seed production. They benefit from an open canopy and from soil disturbances (Rejmánek et al. 2005, Fuentes et al. 2013). Our results support this with $45 \%$ of all alien species being short-lived and with a positive influence of light on alien species cover. Alien shrubs, herbs and graminoids were most abundant after total canopy removal on the $\mathrm{SC}$ and CC option. The most successful alien species in the managed site are Agrostis capillaris, Genista monspessulana and Rumex acetosella, three prominent invasive species in south-central Chile that are able to form monotypic stands (Fuentes et al. 2014). They are characterized by a high plasticity in the invaded range allowing for increased plant sizes, plant densities and seed banks compared to the native range (Rapson \& Bastow Wilson 1992, Herrera et al. 2011). This phenomenon was often observed in alien plant species (Bossdorf et al. 2005). The ability of these species to spread vegetatively and to produce large seed banks characterizes them as superior early colonizers that are able to suppress other species (San Martín \& Donoso 1995, Prach \& Pyšek 1999).

A suppression of native species can be assumed for the CC option showing the lowest native and forest species diversity across the managed site. Mostly affected are tree and shrub species that generally have a low regeneration potential in open areas (Armesto \& Pickett 1985, Fuentes et al. 1986, Becerra \& Montenegro 2013). Most central Chilean tree and shrub species are bird-dispersed. They rely on wind-dispersed early pioneer shrubs offering resting places for birds. By this these shrubs function as recruitment foci for native seeds. Due to the rapid expansion of the alien grass $A$. capillaris in the $\mathrm{CC}$ option forming a continuous sward, few colonization sites were available for wind-dispersed pioneer shrubs (e.g. Baccharis spec.; Holl 1998, 2002).

Soil moisture is another important variable for tree and shrub establishment in central Chile. For the CC option a low AWC was determined indicating a limitation of native tree and shrub establishment by moisture (Holmgren et al. 2000). The dry conditions may have further facilitated the spread of $A$. capillaris, a characteristic species for dry grasslands in its native range (Oberdorfer 2001). Although comparable in soil moisture, the shade provided by the young pines on the PC option probably prevented a similar expansion of alien grasses allowing more native species to colonize. This supports the general hypothesis that the importance of facilitation becomes more prevalent with increasing stress (Bertness \& Callaway 1994).

Our results also indicate that slightly more shade on the strip cut compared to the clear cut and a native canopy compared to a pine canopy allow more native and forest species to establish (Guerrero \& Bustamante 2007, Becerra \& Montenegro 2013). Despite a high diversity of alien species in the SC option benefitting from light and sufficient moisture neither species reached dominance as seen for the clear cut. Higher water availability probably increased the competitive ability of native species against aliens as particularly demonstrated for shrubs and herbs by Mason et al. (2012) in invaded coastal dune communities.

\section{Tree species establishment by planting}

Results from the planting experiment are consistent with native diversity results obtained from vegetation surveys with lowest survival rates in the two water limited options $\mathrm{CC}$ and PC. Lowest values for all three native tree species were found on the CC. Values for the PC option were higher for all three species. This underlines a facilitation effect due to shading provided by the young pine trees. This was already demonstrated before for several evergreen species (Q. saponaria, Lithraea caustica, Peumus boldus) of the Chilean matorral with annual rainfall below $400 \mathrm{~mm}$ (Fuentes et al. 1986). Our results suggest a similar facilitation effect in coastal areas with higher rainfall and for deciduous tree species. The adaptation 
to drought for the planted tree species with survival rates of $Q$. saponaria $>N$. glauca $>N$. obliqua for the two dry options (CC and PC) follows the species distribution centers from the dry north to the moist south of Chile (Luebert \& Pliscoff 2006).

Results indicate that the large expansion of the invasive A. capillaris on the CC not only affected the colonization of native species by seeds from the outside negatively but the survival of planted species as well. As many alien invasive grasses typically have a dense root system in the upper soil horizons the available water was probably taken up by $A$. capillaris before it became accessible to the seedlings (Soriana \& Sala 1983, Williams \& Hobbs 1989). The lower herbaceous cover under pine allowed a higher survival of native trees. Holmgren et al. (2000) demonstrated a positive effect of a removal of the herbaceous layer on the survival of planted $Q$. saponaria and concluded a reduced competition for water. Beccera \& Montenegro (2013) also mention the larger cover of the herb layer on open sites compared to the situation under shade provided by a native or alien canopy as one reason for lower tree species numbers in open patches.

With higher water availability detected for the SC and NC option the facilitation effect provided by a canopy disappeared. Tree species establishment was most successful on the SC option. This supports the model proposed by Holmgren et al. (1997) for mesic sites suggesting that survival and growth decline with shade. The high diversity of alien species had no negative effect on the survival of planted native trees on the SC option providing another indication for a higher competitive ability of natives against invaders under sufficient water availability.

With an overall survival rate of $50 \%$ to $66 \%$ we could show a successful establishment of three different native tree species by planting within a managed site avoiding the sensitive germination stage (Guerrero \& Bustamante 2007, 2009).

\section{Conclusions}

We could show that much of the native and forest plant species diversity is still present within a highly anthropogenic landscape composed of exotic tree plantations in south-central Chile. Some of these species even benefit from management due to high light levels and available colonization sites compared to an unmanaged forest. Our results demonstrate a large potential for preserving native biodiversity in such landscapes despite an ongoing landscape degradation caused by industrial forestry.

The diverse and abundant alien flora that established as a consequence of human disturbance can, however, deter the establishment of native species, especially under dry conditions. Establishment of native trees after planting was unsuccessful after clear cutting and a subsequent expansion of the alien grass A. capillaris. In general our results underline the necessity for understorey vegetation control during native species establishment, in particular when alien grasses are present (Ortega-Pieck et al. 2011).

A successful regeneration at least for a drought-tolerant species such as $Q$. saponar$i a$ is, however, possible even when planted in combination with Pinus radiata. Such a management option might minimize an economic deficit for the forest owner when deciding to increase the proportion of native tree species. The pine trees can provide a nurse effect during early native tree species establishment but should be removed after successful establishment in order to avoid competition and a further expansion of the invasive tree (Becerra \& Montenegra 2013).

Our study contributes to the knowledge of native species establishment in an anthropogenic landscape. Due to the small spatial dimension of our study and a lack of replications we can, however, hardly generalize from our results. More studies are needed contrasting different abiotic conditions and canopy regimes in order to get a broad knowledge on the 
fundamental requirements of native and forest species within Mediterranean Chile. This requires commitment by forest owners for an establishment of experimental sites and for a potential adjustment of forest management in order to integrate conservation and biodiversity issues.

\section{Acknowledgements}

We would like to thank the Bauer Foundation (Bauer Stiftung zur Förderung von Wissenschaft und Forschung) within the Stifterverband für die Deutsche Wissenschaft for funding our research. Furthermore, we are grateful to Felipe A. Jara Santis and Julio A. García Ramírez for data collection, to Ulrike Westphal for analysing soil samples, to Peter Schall for discussing statistical issues and to Ruth Gilbert for language corrections.

\section{References}

Agromet, 2015. Red Agrometereológica de INIA. INIA [Agrometereological Net of the Institute of Agricultural Investigations], Web: http://agromet.inia.cl/estaciones. php. Accessed 16.11.2015.

Aguayo M., Pauchard A., Azócar G., Parra O., 2009. Cambio del uso del suelo en el centro sur de Chile a fines del siglo XX. Entendiendo la dinámica especial y temporal del paisaje [Land use change in south central Chile at the end of the 20th century. Understanding the spatio-temporal dynamics of the landscape]. Revista Chilena Historia Natural 82: 361-374. DOI: $10.4067 /$ S0716-078X2009000300004

Armesto J.J., Pickett S.T.A., 1985. A mechnistic approach to the study of succession in the Chilean matorral. Revista Chilena Historia Natural 58: 9-17.

Armesto J.J., Villagrán C., Arroyo M.K (Eds), 1995. Ecología de los bosques nativos de Chile [Ecology of the native forests of Chile]. Editorial Universitaria, Santiago, Chile, 477 p.

Becerra P.I., Montenegro G., 2013. The widely invasive tree Pinus radiata facilitates regeneration of native woody species in semi-arid ecosystems. Applied Vegetation Science 16: 173-183. DOI: 10.1111/j.1654109X.2012.01221.x

Becerra P.I., Simonetti J.A., 2013. Patterns of exotic species richness of different taxonomic groups in a fragmented landscape of central Chile. Bosque 34: 45-51.
DOI: $10.4067 / \mathrm{S} 0717-92002013000100006$

Bell M.A., van Kleunen H., 1996. Effect of soil disturbance on pedotransfer function development for field capacity. Soil Technology 8: 321-329. DOI: 10.1016/09333630(95)00032-1

Bertness M.D., Callaway R., 1994. Positive interactions in communities. Trends in Ecology and Evolution 9: 191193. DOI: 10.1016/0169-5347(94)90088-4

Bossdorf O., Auge H., Lafuma L., Rogers W.E., Sieman E., Prati D., 2005. Phenotypic and genetic differentiation between native and introduced plant populations. Oecologia 144: 1-11. DOI: 10.1007/s00442-005-0070-z

Braun-Blanquet J., 1964. Pflanzensoziologie: Grundzüge der Vegetationskunde [Plant sociology: Main features of vegetation science], 3rd edn. Springer, Wien, $865 \mathrm{p}$. DOI: 10.1007/978-3-7091-8110-2

Bremer L.L., Farley K.A., 2010. Does plantation forestry restore biodiversity or create green deserts? A synthesis of the effects of land-use transitions on plant species richness. Biodiversity and Conservation 19: 3893-3915. DOI: $10.1007 / \mathrm{s} 10531-010-9936-4$

Carnus J.M., Parrotta J., Brockerhoff E., Abez M., Jactel H., Kremer A., Lamb D., O'Hara K., Walters B., 2006. Planted forests and biodiversity. Journal of Forestry 2: 65-77.

Casanova M., Salazar O., Seguel O., Luzio W., 2013. The soils of Chile. Springer Dodrecht, Heidelberg New York London, 185 p. DOI: 10.1007/978-94-007-5949-7

Chao A., Gotelli N.J., Hsieh T.C., Sander E.L., Ma K.H., Colwell R.K., Ellison A.M., 2014. Rarefaction and extrapolation with Hill numbers: a framework for sampling and estimation in species diversity studies. Ecological Monographs 84: 45-67. DOI: 10.1890/130133.1

Cincotta R.P., Engelman R., 2000. Nature's place - human population and the future of biological diversity. Population Action International, Washington, D.C., 80 p.

Cubbage F., Diaz D., Yapura P., Dube F., 2010. Impacts of forest management certification in Argentina and Chile. Forest Policy and Economics 12: 497-504. DOI: 10.1016/j.forpol.2010. 06.004

Echeverría C., Coomes D., Salas J., Rey-Benayas J.M., Lara A., Newton A., 2006. Rapid deforestation and fragmentation of Chilean Temperate Forests. Biological Conservation 130: 481-494. DOI: 10.1016/j.biocon.2006.01.017

Figueroa J.A., Lusk C.H., 2001. Germination requirements and seedling shade tolerance are not correlated in a Chilean temperate rain forest. New Phytologist 152: 483-489. DOI: 10.1046/j.0028-646X.2001.00282.x

Fuentes E.R., Hoffmann A.J., Poiani A., Alliende M.C., 1986. Vegetation change in large clearings: patterns in the Chilean matorral. Oecologia 68: 358-366. DOI: 10.1007/ BF01036739

Fuentes N., Pauchard A., Sánchez P., Esquivel J., Marticorena A., 2013. A new comprehensive database of alien plant species in Chile based on herbarium records. Biological Invasions 15: 847-858. DOI: 10.1007/ 
s10530-012-0334-6

Fuentes N., Sánchez P., Pauchard A., Urrutia J., Cavieres L., Marticorena A., 2014. Plantas invasoras del Centro-Sur de Chile: Una guía de campo [Invasive plants of south-central Chile: A field guide]. Laboratorio de Invasiones Biológicas (LIB), Concepción, Chile, 276 p.

Gaertner M., Breeyen A.D., Hui C., Richardson D.M., 2009. Impacts of alien plant invasions on species richness in Mediterranean-type ecosystems: a meta-analysis. Progress in Physical Geography 33: 319-338. DOI: 10.1177/0309133309341607

Gómez P., Hahn S., San Martín J., 2009. Estructura y composición florística de un matorral bajo plantaciones de Pinus radiata D.Don en Chile central [Structure and floristic composition of a shrub under Pinus radiata D.Don plantations in central Chile]. Gayana Botanica 66: 256268. DOI: $10.4067 / \mathrm{S} 0717-66432009000200010$

Guerrero P.C., Bustamante R.O., 2007. Can native tree species regenerate in Pinus radiata plantations in Chile? Evidence from field and laboratory experiments. Forest Ecology and Management 253: 97-102. DOI: 10.1016/j.foreco.2007.07.006

Guerrero P.C., Bustamante R.O., 2009. Abiotic alterations caused by forest fragmentation affect tree regeneration: a shade and drought tolerance gradient in the remnants of Coastal Maulino Forest. Revista Chilena Historia Natural 82: 413-424. DOI: 10.4067/S0716078X2009000300008

Herrera A.M., Carruthers R.I., Mills N.J., 2011. Introduced populations of Genista monspessulana (French broom) are more dense and produce a greater seed rain in California, USA, than native populations in the Mediterranean Basin of Europe. Biological Invasions 13: 369-380. DOI: 10.1007/s10530-010-9829-1

Hoffmann A., 2005. Flora Silvestre de Chile - zona araucana [Wild Flora of Chile - Araucanian Zone]. 5th edn, Ediciones Fundacion Galudio Gay, Santiago, Chile, 257 p.

Holl K.D., 1998. Do bird perching structures elevate seed rain and seedling establishment in abandoned tropical pasture? Restoration Ecology 6: 253-261. DOI: 10.1046/j.1526-100X.1998.00638.x

Holl K.D., 2002. Effect of shrubs on tree seedling establishment in an abandoned tropical pasture. Journal of Ecology 90: 179-187. DOI: 10.1046/j.00220477.2001.00637.x

Holmgren M., Scheffer M., Huston M.A., 1997. The interplay of facilitation and competition in plant communities. Ecology 78: 1966-1975. DOI: 10.1890/00129658(1997)078 [1966:TIOFAC]2.0.CO;2

Holmgren M., Segura A.M., Fuentes E.R., 2000. Limiting mechanisms in the regeneration of the Chilean matorral. Plant Ecology 147: 49-57. DOI: 10.1023/A:1009804726307

Lara A., Little C., Urrutia R., McPhee J., Álvarez-Garretón C., Oyarzún C., Soto D., Donoso P., Nahuelhual L., Pino M., Arismendi I., 2009. Assessment of ecosystem services as an opportunity for the conservation management of native forests in Chile. Forest Ecology and Management 258: 415-424. DOI: 10.1016/j.foreco.2009.01.004

Litton C., Santelices R., 1996. Comparación de las comunidades vegetales en bosques Nothofagus glauca (Phil.) Krasser en la Séptima Región de Chile [Comparison of plant communities in Nothofagus glauca (Phil.) Krasser forests in the VII. Region of Chile]. Bosque 17: 77-86. DOI: 10.4206/bosque.1996.v17n2-08

Luebert F., Pliscoff P., 2006. Sinopsis bioclimática y vegetacional de Chile [Bioclimatical and vegetational synopsis of Chile]. Editorial Universitaria, Santiago, Chile, $316 \mathrm{p}$.

Lugo A.E., 1997. The apparent paradox of re-establishing species richness on degraded lands with tree monocultures. Forest Ecology and Management 99: 9-19. DOI: 10.1016/S0378-1127(97)00191-6

Lusk C.H., Donoso C., Jiménez M., Moya C., Oyarce G., Reinso R., Salda-a A., Villegas P., Matus F., 2001. Decomposición de hojarasca de Pinus radiata y tres species arbóreas nativas [Decomposition of leaf litter of Pinus radiata and three native tree species]. Revista Chilena Historia Natural 74: 705-710. DOI: $10.4067 /$ S0716-078X2001000300016

Mason T.J., French K., Russell K., 2012. Are competitive effects of native species on an invader mediated by water availability? Journal of Vegetation Science 23: 657666. DOI: 10.1111/j.1654-1103.2012.01393.x

Mead D.J., 2013. Sustainable management of Pinus radiata plantations. FAO Forestry Paper No. 170. Rome, FAO, 246 p.

Müller-Using B., Bava J., 2010. Neue Gesetze zum Erhalt des Naturwaldes in Chile und in Argentinien - Zwei unterschiedliche Wege zu einem gemeinsamen Ziel [New laws for the conservation of the natural forests in Chile and Argentina - Two different ways to a common aim]. Forstarchiv 81: 21-24.

Muñoz F., Muñoz C., Uribe M., Martín M.A., Molina J.R., Herrera M.Á., Álvarez J.B., Martín L.M., 2013. Composición, estructura y diversidad de poblaciones de Nothofagus glauca ubicadas en la zona mediterránea de Chile [Composition, structure and diversity of populations of Nothofagus glauca located in the Mediterranean zone of Chile]. Gayana Botanica 70: 82-91. DOI: 10.4067/S0717-66432013000100009

Myers N., 1990. The biodiversity challenge: expanded Hot-Spots analysis. The Environmentalist 10: 243-256. DOI: $10.1007 / \mathrm{BF} 02239720$

Myers N., Mittermeier R.A., Mittermeier C.G., da Fonseca G.A.B., Kent J., 2000. Biodiversity hotspots for conservation priorities. Nature 403: 853-858. DOI: $10.1038 / 35002501$

Oberdorfer E., 1960. Pflanzensoziologische Studien in Chile - Ein Vergleich mit Europa [Plant sociological studies in Chile - A comparison with Europe]. Flora et Vegetatio Mundi 2: 1-208.

Oberdorfer E., 2001. Pflanzensoziologische Exkursionsflora [Plant sociological excursion flora]. 8th edn. U1- 
mer, Stuttgart, $1051 \mathrm{p}$.

Oksanen J., Blanchet F.G., Kindt R., Legendre P., Minchin P.R., O’Hara R.B., Simpson G.L., Solymos P., Stevens M.H.H., Wagner H., 2013. vegan: Community Ecology Package. R package version 2.0-10

Ortega-Pieck A., López-Barrera F., Ramírez-Marcial N., García-Franco J.G., 2011. Early seedling establishment of two tropical montane cloud forest tree species: the role of native and exotic grasses. Forest Ecology and Management 261: 1336-1343. DOI: 10.1016/j.foreco. 2011.01.013

Palacios-Bianchi P.A., 2002. Producción y decomposición de hojarasca en un bosque Maulino fragmentado [Production and decomposition of leaf litter in a fragemented Maulino forest]. Web: http://www.mantruc.com/ pilar/seminario-palacios-bianchi2002.pdf. Accessed 19.11.2015.

Prach K., Pyšek P., 1999. How do species dominating in succession differ from others? Journal of Vegetation Science 10: 383-392. DOI: 10.2307/3237067

Pryor D.D., 2010. Analysis of light environments under forest canopies using an integrated digital hemispherical image system. Ph.D. Thesis. Staffordshire University, $182 \mathrm{p}$.

Ramírez C., Figueroa H., Carrillo R., Contreras D., 1984. Estudio fitosociologico de los estratos inferiors en un bosque de pino (Valdivia, Chile) [Phytosociological studies in the understorey of a pine forest (Valdivia Chile)]. Bosque 5: 65-81. DOI: 10.4206/bosque.1 984. v5n2-03

Rapson G.L., Bastow Wilson J., 1992. Genecology of Agrostis capillaris L. (Poaceae) - an invader into New Zealand: 2. Responses to light, soil fertility, and water availability. New Zealand Journal of Botany 30: 13-24. DOI: 10.1080/0028825X.1992.10412881

Rejmánek M., Richardson D.M., Pyšek P., 2005. Plant invasions and invasibility of plant communities. In: van der Maarel E. (ed.), Vegetation ecology. Blackwell, Oxford, pp. 332-355.

Sala O.E., Chapin III F.S., Armesto J.J., Berlow E., Bloomfield J., Dirzo R., Huber-Sanwald E., Huenneke L., Jackson R.B., Kinzig A., Leemans R., Lodge D.M., Mooney H.A., Oesterheld M., Poff N.L., Sykes M.T., Walker B.H., Walker M., Wall D.H., 2000. Global biodiversity scenarios for the year 2100 . Science 287 : 1770-1774. DOI: 10.1126/science.287.5459.1770

San Martín J., Donoso C., 1995. Estructura florística e impacto antrópico en el bosque Maulino de Chile [Floristic structure and human impact on the Maulino forest of Chile]. In: Armesto J.J., Villagrán C., Arroyo M.K. (eds.), Ecología de los bosques nativos de Chile. Editorial Universitaria, Santiago, Chile, pp 153-168.

Soriana A., Sala O., 1983. Ecological strategies in a Patagonian arid steppe. Vegetatio 56: 9-15. DOI: 10.1007/ BF00036131

Williams K., Hobbs R.J., 1989. Control of shrub establishment by springtime soil water availability in an annual grassland. Oecologia 81: 62-66. DOI: 10.1007/ BF00377011

Zuloaga F.O., Morrone O., Belgrano M., 2008. Catálogo de las plantas vasculares del Cono Sur (Argentina, Sur de Brasil, Chile, Paraguay y Uruguay) Volumen I, II, III [Catalogue of the vascular plants of the Southern Cone (Argentina, South of Brazil, Chile, Paraguay and Uruguay) Volumes I, II, III]. Monographs in Systematic Botany 107. St. Louis, Missouri Botanical Garden Press, $3486 \mathrm{p}$.

\section{Supporting Information}

Supp. Info. I. Map of the study area

Supp. Info. II. Schematic diagram of the tree planting experiment

Supp. Info. III. Mean cover values of all sampled species in the management variants and in the unmanaged reference

Supp. Info. IV. Sample-size based rarefaction and extrapolation curves of plant species diversity for each management option against the unmanaged reference 